\title{
Drought Response of Three Ornamental Herbaceous Perennials
}

\author{
Kelly J. Prevete, R. Thomas Fernandez, ${ }^{1}$ and William B. Miller ${ }^{2}$ \\ Department of Horticulture, Clemson University, Clemson, SC 29634-0375
}

\begin{abstract}
ADDitional INDEX wORDs. Boltonia asteroides, Eupatorium rugosum, growth, fructan, leaf gas exchange, leaf water potential, Rudbeckia triloba

Abstract. Boltonia asteroides L. 'Snowbank' (Snowbank boltonia), Eupatorium rugosum L. (eastern white snakeroot), and Rudbeckia triloba $\mathrm{L}$. (three-lobed coneflower) were subjected to drought for 2,4 , and 6 days during the fall and spring. Leaf gas exchange, leaf water potential, growth, and carbohydrate partitioning were measured during drought and throughout the following growing season. Leaf gas exchange of $B$. asteroides was not affected by drought treatment in the fall, not until day 6 of spring drought, and there were no long-term effects on growth. Transpiration and stomatal conductance of $R$. triloba decreased when substrate moisture decreased to $21 \%$ after drought treatment during both seasons. Assimilation of drought-treated $R$. triloba decreased when substrate moisture content decreased to $12 \%$ during spring but was not affected by drought in the fall. There was a decrease in the root-to-shoot ratio of $R$. triloba that had been treated for 4 days, which was attributed to an increase in the shoot dry weight (DW) of treated plants. Reductions in spring growth of $E$. rugosum were observed only after fall drought of 6 days, and there were no differences in final DWs of plants subjected to any of the drought durations. Spring drought had no effect on growth index or DW of any of the perennials. Boltonia asteroides and $R$. triloba had increases in low-molecular-weight sugars on day 4 of drought, but $E$. rugosum did not have an increase in sugars of low molecular weight until day 6 of drought. Differences in drought response of $B$. asteroides, $E$. rugosum, and $R$. triloba were attributed to differences in water use rates.
\end{abstract}

During drought stress plants typically minimize water loss. Some methods of water conservation include decreases in stomatal conductance (Farquhar and Sharkey, 1982; Raschke, 1979), differential growth of roots, shoots, and leaves (Finn and Bunn, 1980; Khalil and Grace, 1992; Palta and Gregory, 1997; Sharp and Davies, 1989), and changes in carbohydrate partitioning (Morgan, 1984; Santamaria et al., 1991). Reduced stomatal conductance may lead to reduced photosynthesis (Fischer et al, 1986; Freeden et al., 1991; Kanechi et al., 1996).

Conversion of sucrose to glucose and fructose may facilitate osmotic adjustment in the leaves of plants under water stress (Morgan, 1984; Santamaria et al., 1991). Osmotic adjustment results in cell turgor maintenance necessary for cell expansion (Boyer, 1988), maintenance of stomatal conductance for gas exchange (Davies and Lakso, 1978; Fernandez and McCree, 1991; McCree and Richardson, 1987), and protection of the photosynthetic apparatus from photoinhibition (Downton, 1983).

We sought to investigate drought responses of Boltonia asteroides 'Snowbank' (Snowbank bolotnia), Eupatorium rugosum (eastern white snakeroot), and Rudbeckia triloba (three-lobed coneflower) which are popular species of ornamental perennials grown commercially in nurseries. Boltonia decurrens is moderately drought tolerant (Smith et al., 1993), but drought tolerance of B. asteroides 'Snowbank' is unknown. Eupatorium rugosum is native to the eastern United States and performs best in well-drained soils (Armitage, 1997). Rudbeckia triloba is native to North America. There is no definitive report of drought tolerance of $R$. triloba, although $R$. hirta (L.) is reportedly drought tolerant (Moore, 1996).

Received for publication 17 June 1999. Accepted for publication 27 Dec. 1999. Support for this research was provided by the South Carolina Agricultural Experiment Station. South Carolina Agricultural Experiment Station technical contribution 4486. The cost of publishing this paper was defrayed in part by the payment of page charges. Under postal regulations, this paper therefore must be hereby marked advertisement solely to indicate this fact.

${ }^{1}$ Current address: Department of Horticulture, Michigan State University, East Lansing, MI 48825-1325.

${ }^{2}$ Current address: Department of Floriculture and Ornamental Horticulture, Cornell University, Ithaca, NY 14853.
All three taxa studied are members of the Asteraceae, which include species that produce fructans (Edelman and Jefford, 1968). The first objective of this study was to determine leaf gas exchange and growth of B. asteroides 'Snowbank', E. rugosum, and R. triloba during drought imposed for 2,4 , or $6 \mathrm{~d}$, and through recovery. The second objective was to determine the role of carbohydrate partitioning in maintenance of leaf gas exchange and growth.

\section{Materials and Methods}

Plant material. Plugs $\left(2.54 \mathrm{~cm}^{2}\right)$ of E. rugosum and R. triloba, from a commercial nursery were potted into $1.9 \mathrm{~L}$ nursery containers on 30 May 1997 and B. asteroides 'Snowbank' on 11 June 1997, filled with a substrate of 4 composted pine bark: 1 river sand (v/v) amended with $6 \mathrm{~kg} \cdot \mathrm{m}^{-3}$ pelletized dolomitic limestone. Plants were liquid fertilized (20N-8.6P-16.6K, Southern Agr. Chemicals, Hendersonville, N.C.) with $\mathrm{N}$ at $150 \mathrm{mg} \cdot \mathrm{L}^{-1} \mathrm{~N}$ at transplant and 1 week before start of treatment. On 16 June $1997,9 \mathrm{~g} /$ container of a slow-release fertilizer (Osmocote 14N-4.2P-11.6K, Scotts-Sierra, Marysville, Ohio) was top dressed to each container. All plants were grown on a gravel nursery area outdoors under natural photoperiod and irradiance at the South Carolina Botanical Garden, Clemson, S.C. Plants were irrigated twice daily to container capacity with overhead sprinkler irrigation of tap water until drought was imposed. Plants were subjected to drought at two times during the growing season: fall to determine if this would affect growth the following spring, and spring to measure effects through the summer.

Plants were placed in a completely randomized design 12 Sept. 1997 for the fall and 1 May 1998 for the spring drought treatments. There were eight replications for all four treatments: 2 , 4, or 6-d drought periods and controls for each of the durations for all taxa for a total of 144 plants. Fall drought was imposed 18 Sept. 1997 (day 0) and spring treatment 8 May 1998 (day 0) by withholding water from the containers. Portable tents were constructed by using 0.03 $\mathrm{mm}$-thick white polyethylene over a 13 -mm-diameter aluminum conduit frame with a height of $1 \mathrm{~m}$, width of $2 \mathrm{~m}$, and length of 3 $\mathrm{m}$. Tents were placed over the plants at dusk and were left on until 
0745 HR to exclude precipitation. Tents also were placed over the plants when there was threat of precipitation during other times. Control plants were irrigated with tap water by hand until runoff twice daily at 0800 and $1500 \mathrm{HR}$. All treated and control plants for each duration were planted in the field in a completely randomized design the day following the end of each drought duration. Field soil was a Cecil sandy loam. Control plants were planted at each field planting to allow assessment of differences in leaf gas exchange as a result of transplant stress. An additional eight replicates of each treatment (144 plants) were grown in the fall for use in destructive analysis of carbohydrates. Plants grown for the spring study were overwintered in their containers on the nursery area and covered for winter protection. Carbohydrate analysis was not repeated in the spring drought study.

WATER MEASUREMENTS. Moisture content of the upper $6 \mathrm{~cm}$ of substrate was randomly measured daily at $1000 \mathrm{HR}$ during drought periods by using a Theta Probe type HH1 measurement device and a Theta Probe type ML1 (Delta-T Devices, Cambridge, U.K.) set on the organic soil setting. Predawn leaf water potential $\left(\Psi_{1}\right)$ of every plant, sampled in random order, was measured on an upper fully expanded leaf by using a pressure bomb (Soilmoisture Equipment Corp, Santa Barbara, Calif.) on days 2, 4, and 6 at $0200 \mathrm{HR}$. Measurements could not be made on day 2 of spring drought because of rain.

LEAF GAS EXCHANGE. Abaxial carbon dioxide assimilation (A), stomatal conductance $\left(\mathrm{g}_{\mathrm{s}}\right)$, and transpiration $(\mathrm{E})$ were randomly measured daily between 1000 and 1350 HR during drought periods and through recovery with an infrared gas analysis system (CIRAS1, PP Systems, Haverhill, Mass.) equipped with a Parkinson broad leaf chamber (model PLC-B; PP Systems). Measurements were taken on the youngest fully expanded leaf of every plant, and plants were assessed in a completely random order. When most leaves of E. rugosum had abscised, measurements were taken on the healthiest remaining leaf. Stomatal conductance could not be determined for $B$. asteroides because the leaves did not fill the leaf chamber.

Growth. Growth index [(height $(\mathrm{cm})+$ width $(\mathrm{cm})) / 2]$ was measured every other day during fall and spring droughts, and then weekly after transplanting during the fall and monthly during the spring and summer. Growth index of fall-treated plants was measured until a killing frost on 3 Nov. 1997. Measurements resumed when new growth started 30 Apr. 1998. Plants were harvested for biomass determination after they had reached full bloom. Falltreated E. rugosum were harvested 7 Sept. 1998, and R. triloba were harvested 4 Aug. 1998. Fall-treated B. asteroides were notharvested because there were $<50 \%$ of the plants still living after they flowered. Roots were harvested by removing a $20-\mathrm{cm}^{3}$ volume of soil from beneath the center of the plant with a shovel. Roots and shoots were placed in a drying oven at $60{ }^{\circ} \mathrm{C}$ for $7 \mathrm{~d}$.

CARbohydrate ANALYSIS. Three mature leaves were harvested from each plant of the eight replicates per treatment on days 0 and 4 of the fall drought. Leaves were immersed in liquid nitrogen and then stored at $-80^{\circ} \mathrm{C}$ until lyophilization. Crown samples were taken at $1130 \mathrm{HR}$ on day 0 of drought, and days of planting in the field (days 3,5 , and 7 ). About $5 \mathrm{~g}$ of tissue were cut from the crown, rinsed with water, immersed in liquid nitrogen, and stored at $-80{ }^{\circ} \mathrm{C}$ until lyophilization. Additional crown tissue samples were taken in midwinter on 30 Jan. 1998 and soon after plants started regrowth, on 5 May 1998.

Carbohydrates were extracted following the method described in Ranwala and Miller (1998) with modifications: samples were boiled at $100{ }^{\circ} \mathrm{C}$ for 15 min to denature enzymes and then placed in a hot water bath at $70{ }^{\circ} \mathrm{C}$ for $30 \mathrm{~min}$.
To determine the amount of low molecular weight sugars partitioned into fructans, the fructose, glucose, and sucrose values before acid hydrolysis were subtracted from the fructose and glucose values after acid hydrolysis. The result was the glucose and fructose amounts that were in all fructans. A preliminary experiment showed that the leaf tissue contained only minimal amounts of fructan, so acid hydrolysis was not conducted on leaf tissue. The crown tissue extracts were adjusted to a final volume of $10 \mathrm{~mL}$ by using highperformance liquid chromatography (HPLC) water at $\mathrm{pH} 8.0,2 \mathrm{~mL}$ was removed and pipetted into a $15-\mathrm{mL}$ glass test tube, to which 1 $\mathrm{mL} 0.2 \mathrm{~mol} \cdot \mathrm{L}^{-1} \mathrm{H}_{2} \mathrm{SO}_{4}$ was added. The test tubes were then placed in a water bath at $100{ }^{\circ} \mathrm{C}$ for $30 \mathrm{~min}$. The test tubes were removed, and $375 \mu \mathrm{L}$ of $2 \mathrm{~mol} \cdot \mathrm{L}^{-1} \mathrm{NaOH}$ was added to each sample to neutralize $\mathrm{pH}$. The natural $\log$ of the peak area of each of the fructans was used to reduce variability and to facilitate separation of means of fructan amounts as described in Legnani (1998).

Substrate moisture, predawn $\Psi_{1}$ and dry weight (DW) data were analyzed using Tukey's Studentized range test as appropriate after analysis of variance (ANOVA). Growth index, $\mathrm{g}_{\mathrm{s}}, \mathrm{E}, \mathrm{A}$, and carbohydrate data were analyzed using repeated measures in time, with eight samples per species per treatment per day. Comparisons were made within taxa between the drought and control treatments.

\section{Results and Discussion}

Substrate moisture content of treated plants was less than that of controls $2 \mathrm{~d}$ after fall drought (DAFD) for all three taxa during the fall treatment (Fig. 1A). Treated E. rugosum had a lower substrate moisture content than treated B. asteroides or $R$. triloba 2 DAFD through 4 DAFD, indicating that E. rugosum developed more intensive stress than the other two taxa. During the spring, substrate moisture of treated plants was less than that of controls for all taxa after $3 \mathrm{~d}$ (Fig. 1B).

During the fall drought, there was a difference in predawn $\Psi_{1}$

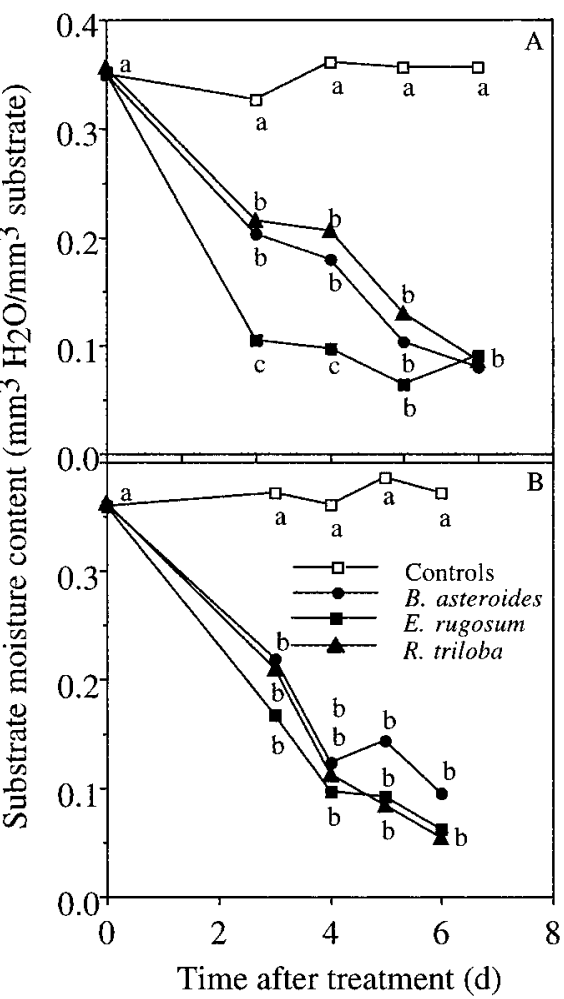
s and treated E. rugosum 2 DAFD, but not until 4DAFD for B. asteroides and $R$. triloba (Table 1). There was no decrease in predawn $\Psi_{1}$ of $B$. aster-

Fig. 1. Substrate moisture content $\left(\mathrm{mm}^{3} \mathrm{H}_{2} \mathrm{O} / \mathrm{mm}^{3}\right.$ substrate) of control (average of controls for all three taxa) ( ); Boltonia asteroides 'Snowbank' treated ( ); Eupatorium rugosum treated ( ); Rudbeckia triloba treated (A) for (A) fall drought, beginning 19Sept. 1997 and (B) spring drought, beginning 8 May 1998 . Legendin(B)applies toboth figures. Comparisons are between the two treatments of all taxa. Means followed by different letters are significantly different at $P \leq$ 0.05 byTukey's Studentized range test. Each point is a mean of eight replicates for controls and treated plants. 
Table 1. Predawn leaf water potential (MPa) for Boltonia asteroides 'Snowbank', Eupatorium rugosum, and Rudbeckia triloba, measured at 0200 HR during fall (19 Sept. 1997, day 0) and spring (8 May 1998, day 0) drought periods.

\begin{tabular}{|c|c|c|c|c|c|}
\hline \multirow[b]{2}{*}{ Treatment } & \multicolumn{3}{|c|}{ Time after fall drought (d) } & \multicolumn{2}{|c|}{ Time after spring drought (d) } \\
\hline & 2 & 4 & 6 & 4 & 6 \\
\hline \multicolumn{6}{|c|}{$\overline{B . \text { asteroides }}$} \\
\hline Control & $-0.1 \mathrm{a}^{\mathrm{z}}$ & $-0.4 \mathrm{a}$ & $-0.4 \mathrm{a}$ & $-0.4 \mathrm{a}$ & $-0.5 \mathrm{a}$ \\
\hline Drought & $-0.2 \mathrm{a}$ & $-1.1 \mathrm{~b}$ & $-1.3 \mathrm{~b}$ & $-0.5 \mathrm{a}$ & $-0.5 \mathrm{a}$ \\
\hline \multicolumn{6}{|l|}{ E. rugosum } \\
\hline Control & $-0.1 \mathrm{a}$ & $-0.4 \mathrm{a}$ & $-0.3 \mathrm{a}$ & $-0.3 \mathrm{a}$ & $-0.3 \mathrm{a}$ \\
\hline Drought & $-1.2 \mathrm{~b}$ & $-2.5 b$ & $-2.1 b$ & $-0.7 \mathrm{~b}$ & $-1.0 \mathrm{~b}$ \\
\hline \multicolumn{6}{|l|}{ R. triloba } \\
\hline Control & $-0.2 \mathrm{a}$ & $-0.5 \mathrm{a}$ & $-0.3 \mathrm{a}$ & $-0.3 \mathrm{a}$ & $-0.3 \mathrm{a}$ \\
\hline Drought & $-0.2 \mathrm{a}$ & $-1.3 \mathrm{~b}$ & $-2.0 \mathrm{~b}$ & $-1.0 \mathrm{~b}$ & $-1.1 \mathrm{~b}$ \\
\hline
\end{tabular}

${ }^{\bar{z}}$ Comparisons are between plants in the drought and control treatments within species for each day. Values are means of eight replications. Means separation by Tukey's studentized range test, $P \leq 0.05$.

oides during the spring drought compared to control (Table 1). There were differences in predawn $\Psi_{1}$ of E. rugosum and $R$. triloba by $4 \mathrm{~d}$ after spring drought (DASD) (Table 1). During water stress, many physiological functions are affected before the leaves show signs of wilting, with cell growth being the most sensitive (Boyer, 1988; Boyer et al., 1985; Hsiao, 1973). A decrease in turgor of enlarging cells is thought to be the cause of reduced growth (Boyer et al., 1985; Green et al., 1971; Mayssek et al., 1988). Predawn $\Psi_{1}$ has been shown effective as a measure of the maximum soil water potential available to roots (Tardieu and Simonneau, 1998). Predawn $\Psi_{1}$ of E. rugosum and $R$. triloba were reduced by a greater amount than in B. asteroides indicating that $B$. asteroides had a lower water use rate.

None of the drought durations during the fall (Fig. 2A) or spring (Fig. 2B) affected A of $B$. asteroides. Effects of drought were more pronounced on $\mathrm{g}_{\mathrm{s}}$ than on A for R. triloba during the fall as found for other species (Freeden et al., 1991; Herde et al., 1997). Stomatal conductance of R. triloba was reduced 51\% 6DAFD compared to control (Fig. 2C), but A was reduced by only 25\% 6DAFD (Fig. 2A). During the spring drought, $\mathrm{g}_{\mathrm{s}}$ and A of $R$. triloba were affected similarly, each reduced by $75 \% 6$ DASD compared to control (Fig. 2). During the fall drought, $\mathrm{g}_{\mathrm{s}}$ of E. rugosum was reduced to $23 \%$ of that of the control $6 \mathrm{DAFD}$, but A was reduced by $100 \% 3$ DAFD (Fig. 2A and C). Assimilation of fall-treated E. rugosum decreased to less than zero 3 DAFD (Fig. 2A), showing that the plants were respiring $\mathrm{CO}_{2}$. Because $\mathrm{g}_{\mathrm{s}}$ was still occurring, $\mathrm{CO}_{2}$ was still available for fixation, suggesting that the limitation to A was nonstomatal. As a result of the spring drought, however, $\mathrm{g}_{\mathrm{s}}$ and A of E. rugosum decreased the same degree suggesting that limitations of $A$ in the spring were due to decreased $g_{s}$. Although the exact mechanisms of the control of stomata over E and A are still unknown (Jarvis and Davies, 1998; Jones, 1998), there was a close relationship between $\mathrm{E}$ and $\mathrm{g}_{\mathrm{s}}$ of E. rugosum and $R$. triloba during drought treatment (Fig. 2C-F). Transpiration of treated E. rugosum decreased 1 $\mathrm{d}$ sooner than $\mathrm{g}_{\mathrm{s}}$ during the fall and on the same
Fig. 2. $\mathrm{CO}_{2}$ assimilation rate, stomatal conductance, and transpiration, during fall drought, beginning 19 Sept. 1997 (A, C, and $\mathbf{E}$ respectively) and during spring drought, beginning 8 May 1998 (B,D, and F, respectively), for Boltonia asteroides 'Snowbank'

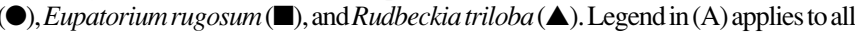
figures. Means $(n=8)$ for a particular taxon are for the drought treatment expressed as a percent of control for that taxon. ${ }^{*, * * * * * *}$ Significantly different means from controls withindays at $P \leq 0.05,0.01$, or 0.001 , respectively. Values are means of eight replicates. Mean separation by repeated measures in time by ANOVA.
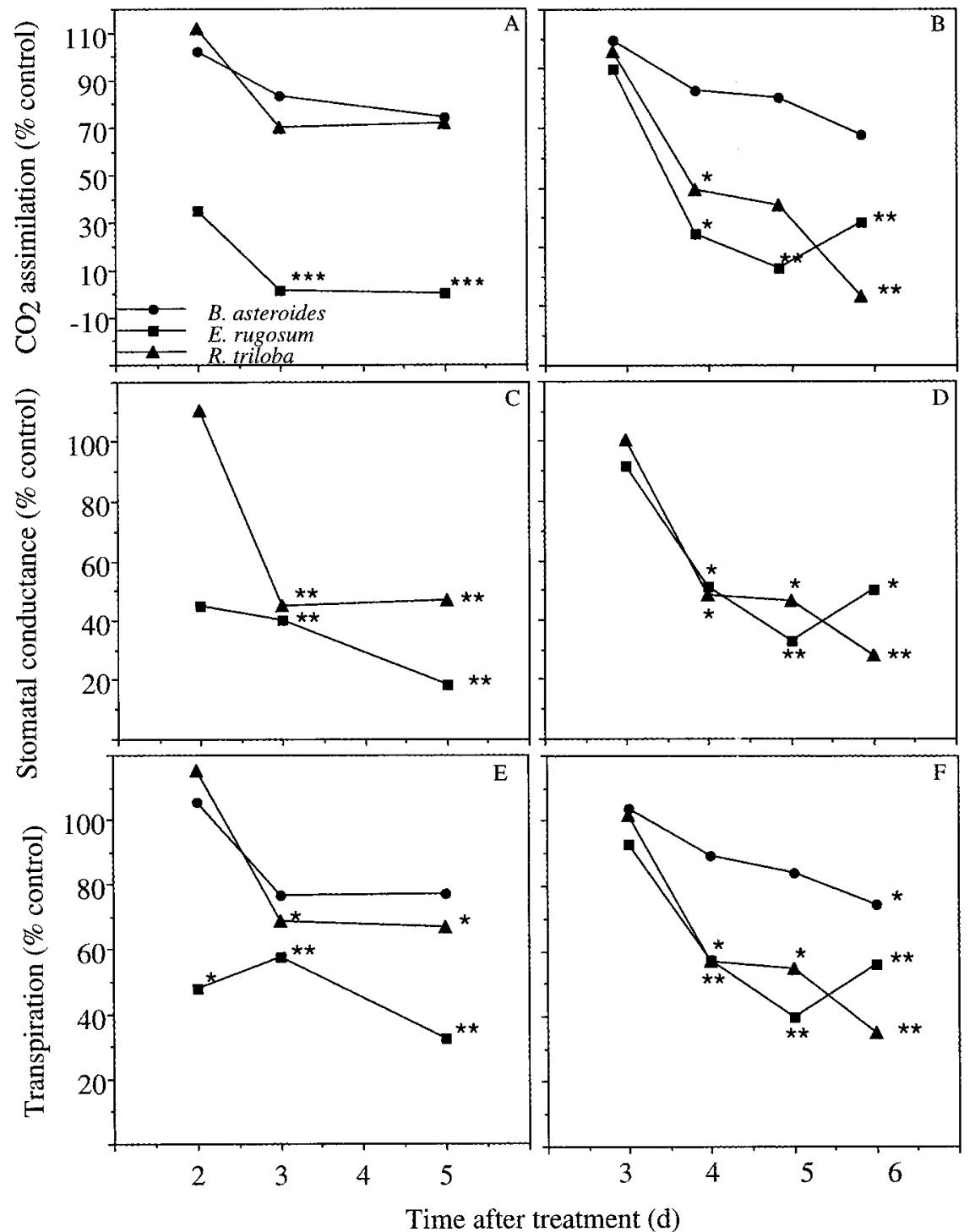

Time after treatment (d) 

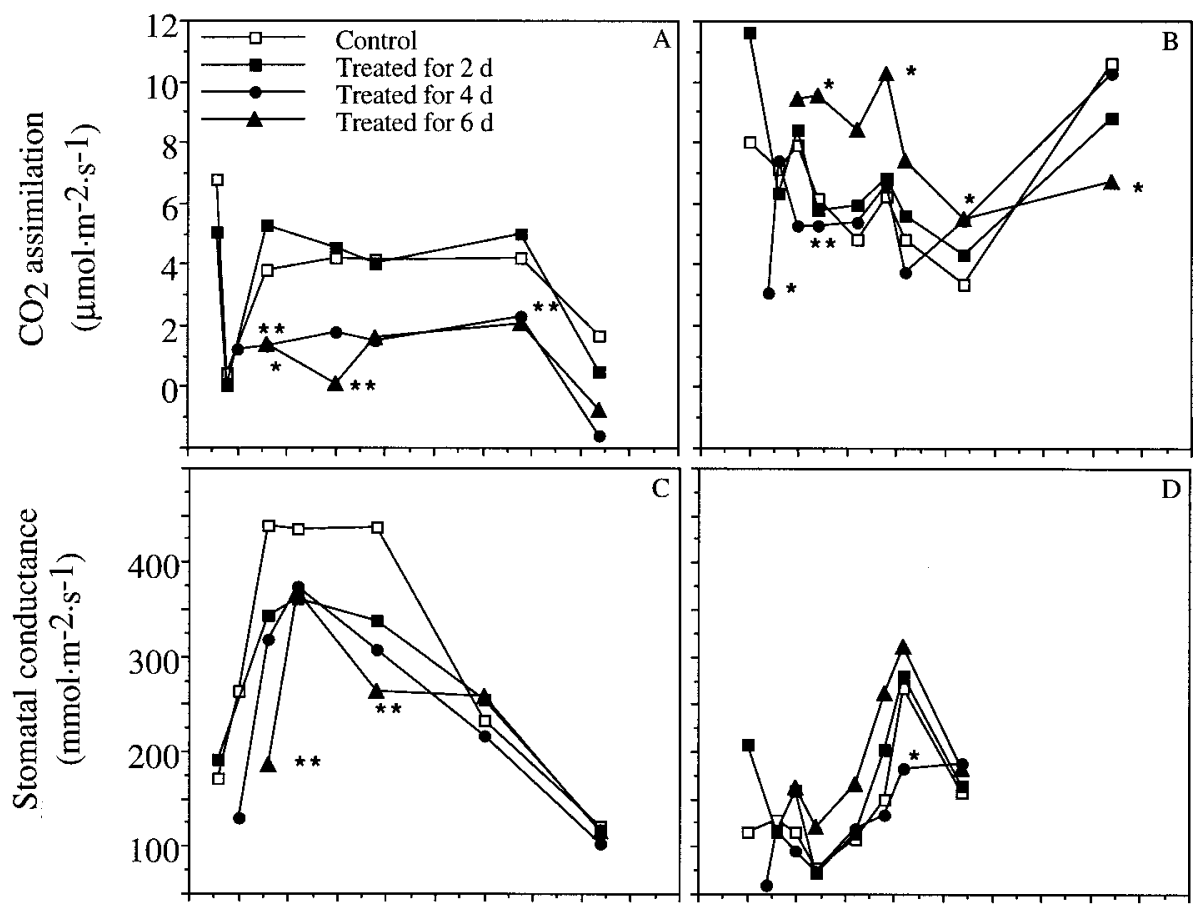

and R. triloba returned to levels of controls the day following rewatering (data not presented). Assimilation of 2-d fall and spring treated $E$. rugosum returned to levels of controls the day following rewatering (Fig. 3A and B). Eupatorium rugosum treated for $4 \mathrm{~d}$ in fall and spring had lower A until 8 DAFD, at which time it returned to levels of controls (Fig. 3A and B). Unlike A of E. rugosum treated for 6 $d$ in the fall, which was less than A of controls for several days during the fall, E. rugosum treated for $6 \mathrm{~d}$ in the spring was greater than $\mathrm{A}$ of the controls on several days (Fig. 3A and B). Stomatal conductance of E. rugosum treated for 2 and $4 \mathrm{~d}$ in the fall and spring returned to levels of controls the day following rewatering (Fig. $3 \mathrm{C}$ and D), however $\mathrm{g}_{\mathrm{s}}$ of E. rugosum treated for $6 \mathrm{~d}$ in the fall was less than $\mathrm{g}_{\mathrm{s}}$ of controls for only $2 \mathrm{~d}$ after rewatering. After rewatering, E of fall-treated E. rugosum returned to levels of controls by 15 DAFD for all treatment periods (Fig. 3E). During recovery from spring drought, $\mathrm{E}$ of all drought periods of E. rugosum returned to levels of controls by 10 DASD (Fig. 3F), however, E values of all drought periods were greater than E of controls 25 DASD.

Neither fall nor spring drought affected growth index of B. asteroides (Fig. 4A). Growth index of fall-treated E. rugosum was not different from that of the controls. Growth index of E. rugosum treated for 4 and $6 \mathrm{~d}$ in the fall was less than the growth index of controls in measurements taken up to 320 DAFD (Fig. 4B). Growth index of E. rugosum had returned to levels of controls by the date of harvest 355 DAFD. Spring drought had no effect on the growth index of E. rugosum. Growth index of $R$. triloba treated for $2 \mathrm{~d}$ in the fall was greater than growth index of

Fig. 3. $\mathrm{CO}_{2}$ assimilation rate, stomatal conductance, and transpiration of Eupatorium rugosum during recovery from fall drought (19 Sept. 1997, day 0) (A, C, and E, respectively), and during recovery from spring drought (8 May 1998, day 0) (B, $\mathbf{D}$, and $\mathbf{F}$, respectively). Legend in (A) applies to all figures. ${ }^{*}, *$ Significantly different means from controls within days at $P \leq 0.05$ or 0.001 , respectively. Values are means of eight replications. Mean separation by repeated measures in time by ANOVA.

day for E. rugosum and R. triloba during the spring and R. triloba during the fall (Fig. 2C-F). There was a reduction in $\mathrm{g}_{\mathrm{s}}$ and $\mathrm{E}$ of $E$. rugosum when substrate moisture content was $10 \%$, and there may have been a reduction sooner, but leaf gas exchange was not measured until 2 DAFD. Rudbeckia triloba had a decrease in $g_{s}$ when substrate moisture content was $21 \%$. Average values of A for control plants of B. asteroides, E. rugosum, and R. triloba were 14, 6 , and $9 \mu \mathrm{mol} \cdot \mathrm{m}^{-2} \cdot \mathrm{s}^{-1}$ during the fall and 20,8 , and $15 \mu \mathrm{mol} \cdot \mathrm{m}^{-2} \cdot \mathrm{s}^{-1}$ in the spring, respectively. Average values of $\mathrm{g}_{\mathrm{s}}$ for control plants of $E$. rugosum and $R$. triloba were 300 and $375 \mathrm{mmol} \cdot \mathrm{m}^{-2} \cdot \mathrm{s}^{-1}$ during the fall, and 115 and $250 \mathrm{mmol} \cdot \mathrm{m}^{-2} \cdot \mathrm{s}^{-1}$ in the spring, respectively. Average values of $\mathrm{E}$ for control plants of B. asteroides, E. rugosum, and $R$. triloba were 8,5 , and $7 \mathrm{mmol} \cdot \mathrm{m}^{-2} \cdot \mathrm{s}^{-1}$ during the fall and 10 , 4 , and $6 \mu \mathrm{mol} \cdot \mathrm{m}^{-2} \cdot \mathrm{s}^{-1}$ in the spring, respectively.

Assimilation, $\mathrm{g}_{\mathrm{s}}$, and $\mathrm{E}$ of fall- and spring-treated $B$. asteroides controls 280 DAFD, but returned to nontreated levels by 320 DAFD (Fig. 4C). Growth index of $R$. triloba treated for $4 \mathrm{~d}$ in the fall was less than growth index of the controls from 250 DAFD through 280 DAFD, but had returned to levels of controls by 320 DAFD (Fig. 4C). The growth index of $R$. triloba treated for $6 \mathrm{~d}$ in the fall was not different from growth index of the controls (Fig. 4C). The root-toshoot ratio of $R$. triloba treated for $4 \mathrm{~d}$ in the fall was 0.98 compared to 1.8 for the control at harvest. The decrease in the root-to-shoot ratio of treated $R$. triloba was attributed to an increase in shoot DW from $200 \mathrm{~g}$ for the control to $290 \mathrm{~g}$ for the treated. There was no difference in the root-to-shoot ratio of $R$. triloba treated for $6 \mathrm{~d}$ in the fall compared to the control, which may have been due to higher root turnover during the longer stress (Gregory and Atwell, 1991; Smucker, 1984, 1993). Water stress decreases shoot growth more than root growth in many plant species, resulting in a lower shootto-root ratio (Finn and Bunn, 1980; Khalil and Grace, 1992; Palta and Gregory, 1997; Sharp and Davies, 1989).

Differences in the ability of species to adjust osmotically during drought stress influence the ability of plants to tolerate drought (Chapman and Augé, 1994; Nguyen et al., 1997; Premanchandra et al., 1995). Helianthus angustifolius L.) (swamp sunflower) was found to be less drought tolerant than Rudbeckia fulgida var. 
Fig. 4. Spring growth index ((height + width)/2) (cm) of fall-treated (A)Boltonia asteroides 'Snowbank', (B)Eupatorium rugosum, and (C)Rudbeckia triloba. Legend in (A) applies to all figures. Measurements began on 15 Apr. 1998. **** Significantly different means from control within days at $P \leq 0.05$ or 0.001 , respectively. Values are means of eight replications. Mean separation by pairwise $t$ test.

Sullivanti (Beadle \& Boynt.) Cronq (black-eyed susan), and these differences were attributed to osmotic adjustment (Chapman and Augé, 1994). A study with $H$. annuus L. (sunflower) showed that, during drought stress, starch was hydrolyzed and sucrose concentration increased (Freeden et al., 1991). In Phaseolis vulgaris L. 'Tacariqua' (Tacariqua bean) plants under drought stress, the starch/sucrose ratio decreased and the glucose/fructose ratio increased (Castrillo, 1992). There were increased activities of sucrose invertase, sucrose synthase, and starch-hydrolyzing enzymes (amylases) in Cajanus cajan L. (pigeonpea) plants under drought stress (Keller and Ludlow, 1993). Boltonia asteroides leaves had a higher concentration of glucose, sucrose, and fructose after treatment for $4 \mathrm{~d}$ (Table 2). This change in carbohydrate partitioning apparently was not a result of the breakdown of sucrose, however,

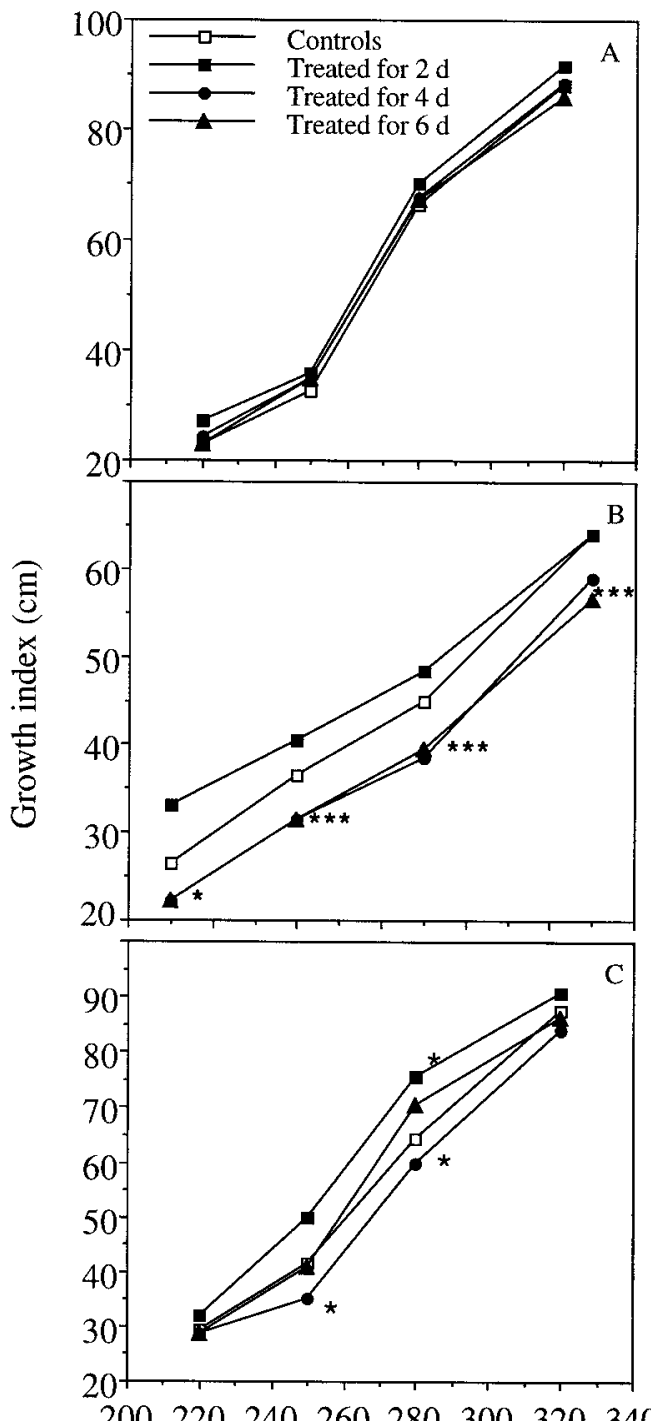

$\begin{array}{llllllll}200 & 220 & 240 & 260 & 280 & 300 & 320 & 340\end{array}$

Time after treatment during fall (d) because the sucrose level increased as well. Because there were no fructans present in the leaves of $B$. asteroides, the build up of sucrose in the leaves may have been a result of decreased transport of sucrose out of the leaves. Sucrose becomes concentrated in leaves during drought due to reduced sucrose export from the leaves, which is thought to be due to reduced export of protons that are the cotransporters of sucrose in the phloem(Malek and Baker, 1978). In plants of other species, accumulation of phototsynthates in the leaves during drought (Ackerson, 1980; Azcon-Bieto, 1983) has acted as a feedback-inhibition mechanism (Janoudi et al., 1993) to A. Eupatorium rugosum had the most stable carbohydrate partitioning in the leaves compared to the other taxa, having only an increase in fructose content (Table 2). Glucose and sucrose contents in the leaves of treated $R$. triloba were greater than the content of the controls 4 DAFD (Table 2).

Because there are no standards for fructans, concentration of each individual fructan could not be determined. Comparisons were made between the natural log of the peak areas per gram DW of the control and treated for each fructan. Although no attempts were made to isolate the longer-chain sugars, other workers (Chatterton et al., 1989; Legnani, 1998) have indicated that the peak with a retention time of $\approx 8$ min is 1-kestose, a trisaccharide intermediate. Each subsequent peak increases the chain of the fructan by one fructose unit; for example, degree of polymerization 5 (DP 5) having one more fructose than DP 4.

Six days after fall drought, the peak area of sucrose in the crown tissue of treated $B$. asteroides was greater than that of the control

Table 2. Soluble sugars ( $\mathrm{mg} \cdot \mathrm{g}^{-1}$ dry weight) in leaf tissue of Boltonia asteroides 'Snowbank', Eupatorium rugosum, and Rudbeckia triloba, on day 0 (19 Sept. 1997) and day 4 of drought during fall.

\begin{tabular}{|c|c|c|c|c|c|c|}
\hline \multirow[b]{3}{*}{ Treatment } & \multicolumn{2}{|c|}{ Sucrose } & \multicolumn{2}{|c|}{ Glucose } & \multicolumn{2}{|c|}{ Fructose } \\
\hline & \multicolumn{6}{|c|}{ Time after fall drought (d) } \\
\hline & 0 & 4 & 0 & 4 & 0 & 4 \\
\hline \multicolumn{7}{|l|}{ B. asteroides } \\
\hline Control & 12 & 12 & 2 & 4 & 1 & 4 \\
\hline Drought & 12 & 28 & 2 & 14 & 1 & 11 \\
\hline Significance & $--{ }^{\mathrm{z}}$ & $* * *$ & --- & $* * *$ & --- & $* * *$ \\
\hline \multicolumn{7}{|l|}{ E. rugosum } \\
\hline Control & 16 & 16 & 8 & 9 & 12 & 12 \\
\hline Drought & 16 & 18 & 8 & 10 & 12 & 22 \\
\hline Significance & --- & NS & --- & NS & --- & $*$ \\
\hline \multicolumn{7}{|l|}{ R. triloba } \\
\hline Control & 8 & 10 & 1 & 2 & 1 & 4 \\
\hline Drought & 8 & 24 & 1 & 4 & 1 & 6 \\
\hline Significance & --- & $* * *$ & --- & $*$ & --- & NS \\
\hline
\end{tabular}

ZThe same tissue was used for the two treatments on day 0.

ss, ${ }^{* * * * *}$ Nonsignificant or significant at $P \leq 0.05$ or 0.001 , respectively. Comparisons are between the treatments within species for each day. Values are means of eight replications. Mean separation by pairwise $t$ test. 
Fig. 5. Soluble sugars in the crown tissue of (A)Boltonia asteroides 'Snowbank', (B)Eupatorium rugosum and (C)Rudbeckia triloba during a fall drought as a percentage of control. Treatment began 19Sept. 1997. Comparisons are between the treated and controls within the same taxon. ${ }^{*, * *}$ Significantly different means from controls within days at $P \leq 0.05$ or 0.01 , respectively. Values are means of eight replications. Mean separation by repeated measures in time by ANOVA.

(Fig. 5A). Fructose of treated $E$. rugosum was greater than that of the control 4DAFD, and sucrose and glucose were greater than the respective control values 6 DAFDintreatedE.rugosum (Fig. 5B). On day 6 of drought, fructose and glucose in treated $R$. triloba were greater than those of the control (Fig. 5C). There were no differences in glucose, fructose, or sucrose in crown tissue between treated and control plants for all three species in samples taken 30 Jan. 1997 and 5 May 1998 (data not presented).

There was no difference in the total fructan content or average fructan length between treated and control $B$. asteroides at any measurement date (Table 3 ). The amount of glucose and fructose attributed to fructans in the crown tissue of E. rugosum was less than that of the control starting 4 DAFD. The average fructan length of $E$. rugosum treated for $6 \mathrm{~d}$ was DP 3 compared to DP 7 for control plants.

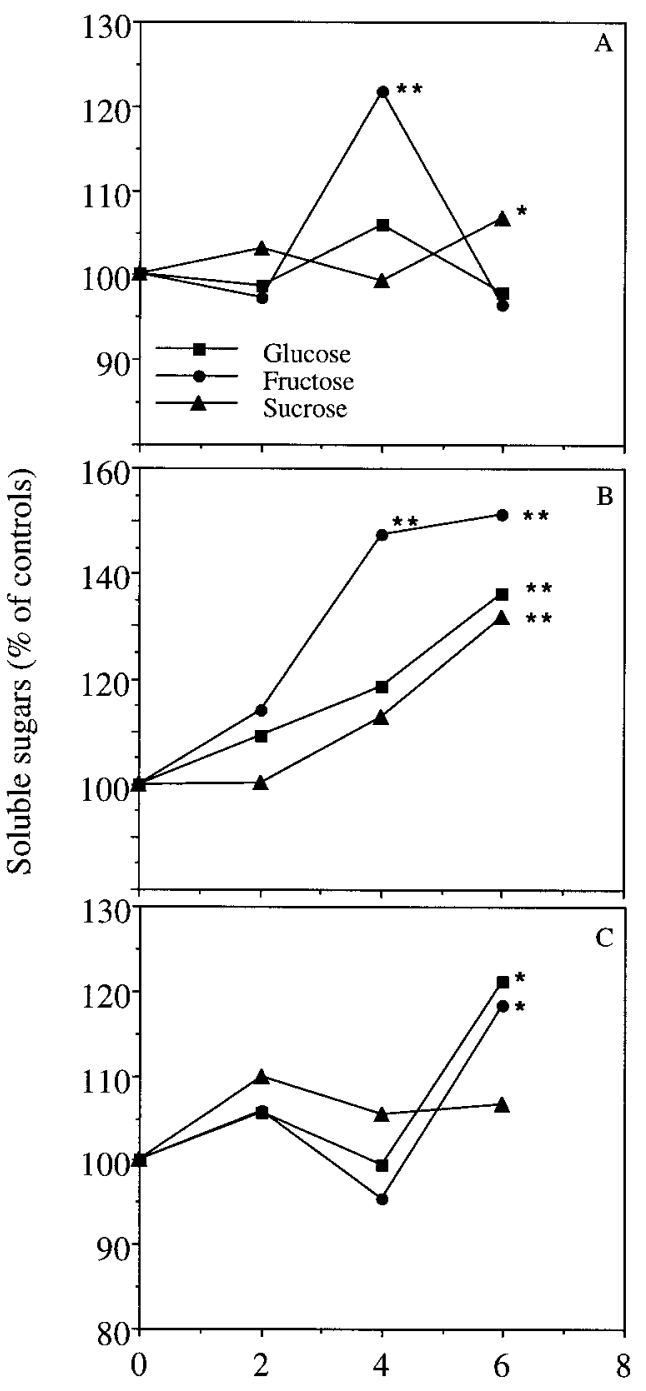

Time after treatment $(\mathrm{d})$
There were no differences in the average fructan length in the crown tissue between control and treated $R$. triloba during drought. The total amount of sugars attributed to fructans in the crown tissue of treated $R$. triloba was greater than that of the control 2 DAFD (Table 3). Total fructan content in crown tissue of $R$. triloba treated for $2 \mathrm{~d}$ was $250 \%$ of control 120 DAFD and $300 \%$ of control 210 DAFD (data not presented). Possibly, as a result of the greater availability of carbohydrates for growth, the growth index of these plants was greater than that of the control throughout the spring but returned to control levels by the beginning of the summer.

On day 6 of drought, 1-kestose and DP 5 content of $B$. asteroides subjected to drought were greater than those of the control (Table 4). Correspondingly, there was a decrease in DP 22, 25, and 26 content in treated $B$. asteroides compared to the control 6 DAFD (Table 4). A similar trend was observed in E. rugosum (Table 4). Although treated E. rugosum had a more pronounced change in carbohydrate partitioning in crown tissue compared to leaf tissue, the other taxa had changes in carbohydrate partitioning $2 \mathrm{~d}$ sooner. Treated $R$. triloba showed little change in carbohydrate partitioning in the leaves, however, there was a more pronounced change in carbohydrate partitioning in the crown tissue. Treated $R$. triloba had an increase in the lower-molecular-weight sugars in crown tissue sooner than the other two taxa. On day 2 of drought, 1-kestose and DP 4 and 5 content had increased in treated $R$. triloba, with DP 5 returning to control levels by day 6 (Table 4), possibly as a result of increased transport into the root tissue. Control values for 1-kestose, DP 4-6, and DP 22-26 for days $0,2,4$, and 6 of treatment for all taxa are presented in Table 5.

Changes in the amount of a particular fructan can be a result of synthesis of fructans or depoly-

Table 3. Amount of glucose and fructose in fructans $\left(\mu \mathrm{mol} \cdot \mathrm{g}^{-1} \mathrm{dry}\right.$ weight $)$ in crown tissue of Boltonia asteroides 'Snowbank', Eupatorium rugosum, and Rudbeckia triloba.

\begin{tabular}{|c|c|c|c|c|c|c|}
\hline \multirow[b]{3}{*}{ Treatment } & \multicolumn{3}{|c|}{ Glucose } & \multicolumn{3}{|c|}{ Fructose } \\
\hline & \multicolumn{6}{|c|}{ Time after fall drought (d) } \\
\hline & 2 & 4 & 6 & 2 & 4 & 6 \\
\hline \multicolumn{7}{|l|}{ B. asteroides } \\
\hline Control & 48 & 80 & 44 & 143 & 221 & 190 \\
\hline Drought & 41 & 54 & 49 & 98 & 171 & 192 \\
\hline Significance & NS & NS & NS & NS & NS & NS \\
\hline \multicolumn{7}{|l|}{ E. rugosum } \\
\hline Control & 14 & 47 & 20 & 91 & 140 & 156 \\
\hline Drought & 33 & 7 & 25 & 95 & 39 & 43 \\
\hline Significance & NS & $* *$ & NS & NS & $* *$ & $* *$ \\
\hline \multicolumn{7}{|l|}{ R. triloba } \\
\hline Control & 26 & 9 & 22 & 76 & 87 & 102 \\
\hline Drought & 60 & 13 & 26 & 244 & 84 & 97 \\
\hline Significance & $* *$ & NS & NS & $* *$ & NS & NS \\
\hline
\end{tabular}


Table 4. Low and high degree of polymerization (DP) of fructans in the crown tissue of Boltonia asteroides 'Snowbank', Eupatorium rugosum, and Rudbeckia triloba during fall drought shown as a percentage of control.

\begin{tabular}{|c|c|c|c|c|c|c|c|c|c|c|c|c|}
\hline \multirow[b]{3}{*}{ Fructan } & \multicolumn{4}{|c|}{ B. asteroides } & \multicolumn{4}{|c|}{ E. rugosum } & \multicolumn{4}{|c|}{ R. triloba } \\
\hline & \multicolumn{12}{|c|}{ Time after fall drought (d) } \\
\hline & 0 & 2 & 4 & 6 & 0 & 2 & 4 & 6 & 0 & 2 & 4 & 6 \\
\hline$\overline{1-\text { kestose }}$ & $100^{2}$ & 95 & 104 & 111 & 100 & 100 & 109 & $137^{*}$ & 100 & $117^{* *}$ & 114 & $119^{* *}$ \\
\hline DP 4 & 100 & 95 & 102 & $113^{*}$ & 100 & 115 & 114 & $142^{*}$ & 100 & $117^{* * *}$ & $110^{* * *}$ & $113^{*}$ \\
\hline DP 5 & 100 & 112 & 93 & $115^{*}$ & 100 & 115 & 116 & $154^{*}$ & 100 & $114^{*}$ & 111 & 107 \\
\hline DP 6 & 100 & 95 & 99 & 106 & 100 & 115 & 108 & $156^{*}$ & 100 & 112 & $116^{*}$ & 108 \\
\hline DP 22 & 100 & 123 & $80^{*}$ & 84 & 100 & 96 & 93 & $76^{* * * *}$ & 100 & 64 & 86 & 111 \\
\hline DP 23 & 100 & 114 & $60^{*}$ & 82 & 100 & 96 & 92 & $85^{*}$ & 100 & 68 & 88 & 102 \\
\hline DP 24 & 100 & 128 & 75 & 81 & 100 & 95 & 92 & 84 & 100 & 68 & 86 & 103 \\
\hline DP 25 & 100 & 119 & $64^{*}$ & 81 & 100 & 96 & 90 & $78^{* * *}$ & 100 & 65 & 72 & 96 \\
\hline DP 26 & 100 & $164^{*}$ & 67 & 76 & 100 & 97 & 90 & $77^{* * *}$ & 100 & 76 & 90 & 111 \\
\hline
\end{tabular}

${ }^{\mathrm{z}}$ Comparisons are between the treated and controls within the same taxon.

${ }^{*, * *, * * *}$ Significantly different means from controls within days at $P \leq 0.05,0.01$, or 0.001 , respectively. Values are means of eight replications. Mean separation by repeated measures in time by ANOVA.

merization of longer-chain fructans (Bieleski, 1993; van den Ende and van Laere, 1996). All taxa in this study had an increase in 1kestose and the lower-order DP fructans as a result of drought and a corresponding decrease in the highest DP fructans (Table 4). Analysis of the intermediate DP fructans showed no difference in quantities (data not presented). It is apparent that the longest-chain fructans are the ones that depolymerize in response to drought.

Depolymerization of fructans results in shorter-chain fructans and free fructose units, which can contribute to osmotic adjustment (Bieleski, 1993; Hendry, 1993; Pilon-Smits et al., 1995). Following drought stress, growth rate and fresh and DWs were higher in transgenic, fructan-accumulating Nicotiana tabacum L. (tobacco) plants than in wild-type plants (Pilon-Smits et al., 1995). The presence of fructans in many species from arid regions and regions of intense cold suggests they may play a role in helping plants survive environmental stresses (Hendry, 1993). The presence of fructans does not guarantee greater drought tolerance. All taxa in this study contained fructans, but only $B$. asteroides and $R$. triloba had rapid changes in carbohydrate partitioning during drought and were able to maintain photosynthesis and growth.

Boltonia asteroides maintained photosynthesis during treatment, and there were no differences in growth index as a result of fall or spring drought. Maintenance of photosynthesis was attributed to an increase in low-molecular-weight sugars in the leaves, perhaps enabling $B$. asteroides to maintain turgor to greater soil water deficits than the other two taxa. Maintenance of photosynthesis provides essential carbohydrates for growth, and there was no decrease in growth index of treated $B$. asteroides compared to the controls.

Rudbeckia triloba had an increase in sugars of lower molecular weight in leaf and crown tissue in response to drought, which may have provided more available carbohydrates for growth the following spring, when we found a high growth index. Eupatorium rugosum had slower changes in carbohydrate partitioning than $B$. asteroides and $R$. triloba. The severe water loss from E. rugosum during drought could be attributed to rapid reductions in soil moisture and lack of adjustments of carbohydrates in the leaves. The amount of water lost from E. rugosum caused long-term decreases in photosynthesis, resulting in reduced amounts of carbohydrates available for growth. Growth index of E. rugosum was decreased for several months as a result of drought. Many factors contribute to drought tolerance or lack of drought tolerance of plants. Boltonia asteroides was able to maintain photosynthesis and growth during drought periods that decreased growth of $R$. triloba and photosynthesis and growth of E. rugosum. Maintenance of photosynthesis and growth of $B$. asteroides may be the result of a relatively low rate

Table 5. Low and high degree of polymerization (DP) fructans in crown tissue of control plants of Boltonia asteroides 'Snowbank', Eupatorium rugosum, and Rudbeckia triloba on days 0 (19 Sept. 1997), 2, 4, and 6 of fall treatment. ${ }^{\mathrm{z}}$

\begin{tabular}{|c|c|c|c|c|c|c|c|c|c|c|c|c|}
\hline \multirow[b]{4}{*}{ Fructan } & \multicolumn{4}{|c|}{ B. asteroides } & \multicolumn{4}{|c|}{ E. rugosum } & \multicolumn{4}{|c|}{ R. triloba } \\
\hline & \multicolumn{12}{|c|}{ Fructans (ln peak area/g dry wt) } \\
\hline & \multicolumn{12}{|c|}{ Time after fall drought (d) } \\
\hline & 0 & 2 & 4 & 6 & 0 & 2 & 4 & 6 & 0 & 2 & 4 & 6 \\
\hline 1-kestose & 125 & 110 & 122 & 128 & 106 & 106 & 106 & 93 & 104 & 96 & 105 & 110 \\
\hline DP 4 & 128 & 112 & 118 & 115 & 97 & 81 & 83 & 75 & 103 & 92 & 100 & 106 \\
\hline DP 5 & 124 & 113 & 120 & 112 & 99 & 73 & 83 & 64 & 103 & 95 & 97 & 107 \\
\hline DP 6 & 125 & 114 & 122 & 115 & 101 & 75 & 86 & 63 & 107 & 97 & 89 & 104 \\
\hline DP 22 & 84 & 75 & 90 & 83 & 72 & 83 & 84 & 83 & 74 & 81 & 77 & 74 \\
\hline DP 23 & 80 & 71 & 86 & 79 & 68 & 81 & 82 & 78 & 70 & 77 & 74 & 73 \\
\hline DP 24 & 69 & 61 & 77 & 69 & 64 & 78 & 78 & 78 & 65 & 74 & 71 & 67 \\
\hline DP 25 & 75 & 67 & 82 & 74 & 60 & 74 & 74 & 76 & 60 & 71 & 69 & 65 \\
\hline DP 26 & 64 & 57 & 71 & 64 & 56 & 70 & 70 & 72 & 55 & 64 & 61 & 57 \\
\hline
\end{tabular}

zValues represent means of eight controls for each taxon. 
of water use by B. asteroides, which may be attributed to many things including smaller leaves and a less fibrous root system. Further study is needed to determine if, under the same drought intensity that $R$. triloba and E. rugosum experienced in this experiment, photosynthesis and growth of $B$. asteroides would also be decreased.

\section{Literature Cited}

Ackerson, R.C. 1980. Stomatal responses of cotton to water stress and abscisic acid as affected by water stress history. Plant Physiol. 64:455-459.

Armitage, A.M. 1997. Herbaceous perennial plants: A treatise on their identification, culture, and garden attributes. 2nd ed. Varsity Press, Athens, Ga.

Azcon-Bieto, J. 1983. Inhibition of photosynthesis by carbohydrates in wheat leaves. Plant Physiol. 73:681-686.

Bieleski, R.L. 1993. Fructan hydrolysis drives petal expansion in the ephemeral daylily flower. Plant Physiol. 103:213-219.

Boyer, J.S. 1988. Cell enlargement and growth-induced water potentials. Physiol. Plant. 73:311-316.

Boyer, J.S., A.J Cavalieri, and E.D. Schulze. 1985. Control of cell enlargement: Effects of excision, wall relaxation, and growth-induced water potentials. Planta 163:527-543.

Castrillo, M. 1992. Sucrose metabolism in bean plants under water deficit. J. Expt. Bot. 43:1557-1561.

Chapman, D.S. and R.M. Augé. 1994. Physiological mechanisms of drought tolerance in four native ornamental perennials. J. Amer. Soc. Hort. Sci. 119:299-306.

Chatterton, N.J., P.A. Harrison, W.R. Thornley, and J.H. Bennett. 1989. Purification and quantification of kestoses (fructylsucroses) by gel permeation and anion exchange chromotography. Plant Physiol. Biochem. 27:289-295.

Davies, F.S. and A.N. Lakso. 1978. Water relations in apple seedlings: Changes in water potential components, abscisic acid, leaf and stomatal conductances under irrigated and non-irrigated conditions. J. Amer. Soc. Hort. Sci. 103:310 313 .

Downton, W.J.S. 1983. Osmotic adjustment during water stress protects the photosynthetic apparatus against photoinhibition. Plant Sci. Lett. 30:137143.

Edelman, J. and T.G. Jefford. 1968. The mechanism of fructosan metabolism in higher plants as exemplified in Helianthus tuberosus. New Phytol. 67:517531.

Farquhar, G.D. and T.D. Sharkey. 1982. Stomatal conductance and photosynthesis. Annu. Rev. Plant Physiol. 33:317-345.

Fernandez, C.J. and K.J. McCree. 1991. Visualizing differences in plant water dynamics with a simulation model. Crop. Sci. 31:399-404.

Finn, G.A. and W.A. Bunn. 1980. Water stress effects on $\mathrm{CO}_{2}$ assimilation, photosynthate partitioning, stomatal resistance, and nodule activity in soybean. Crop Sci. 20:431-434.

Fischer, E., K. Raschke, and M. Sitt. 1986. Effects of abscisic acid on photosynthesis in whole leaves: Changes in $\mathrm{CO}_{2}$ assimilation, levels of carbonreduction-cycle intermediates, and activity of ribulose-1,5-bisphosphate carboxylase. Planta 169:536-545.

Freeden, A.L., J.A. Gamon, and C.B. Field. 1991. Responses of photosynthesis and carbohydrate-partitioning to limitations in nitrogen and water availability in field-grown sunflower. Plant Cell Environ. 14:963-970.

Green, P.B., R.O. Erikson, and J. Buggy. 1971. Metabolic and physical control of cell elongation rate. Plant Physiol. 47:423-430.

Gregory, P.J. and B.J. Atwell. 1991. The fate of carbon in pulse-labeled crops of barley and wheat. Plant Soil. 136:205-213.

Hendry, G.A.F. 1993. Evolutionary origins and natural functions of fructansA climatological, biogeographic and mechanistic appraisal. New Phytol. 123:3-14

Herde, O., H. Pena-Cortes, L. Willmitzer, and J. Fisahn. 1997. Stomatal responses to jasmonic acid, linolenic and abscisic acid in wild-type and ABAdeficient tomato plants. Plant Cell Environ. 20:136-141.

Hsiao, T.C. 1973. Plant responses to water stress. Annu. Rev. Plant Physiol. 24:519-570.
Janoudi, A.K, I.E. Widders, and J.A. Flore. 1993. Water deficits and environmental factors affect photosynthesis in leaves of cucumber (Cucumis sativus). J. Amer. Soc. Hort. Sci. 118:366-370.

Jarvis, A.J. and W.J. Davies. 1998. The coupled response of stomatal conductance to photosynthesis and transpiration. J. Expt. Bot. 49:399-406.

Jones, H.G. 1998. Stomatal control of photosynthesis and transpiration. J. Expt. Bot. 49:387-398.

Kanechi, M., N. Ucida, T. Yasuda, and T. Yamaguchi. 1996. Non-stomatal inhibition associated with inactivation of Rubisco in dehydrated coffee leaves under unshaded and shaded conditions. Plant Cell Physiol. 37:455-460.

Keller, F. and M.M. Ludlow. 1993. Carbohydrate metabolism in droughtstressed leaves of pigeonpea (Cajanus cajan). J. Expt. Bot. 44:1351-1359.

Khalil, A.A.M. and J.Grace. 1992. Acclimation to drought in Acerpseudoplatanus L. (aycamore) seedlings. J. Expt. Bot. 43:1591-1602.

Kramer, P.J. 1987. The role of water stress in tree growth. J. Arboricult. 13:3338.

Legnani, G. 1998. The effects of photoperiod on growth, development, and carbohydrate storage of Dahlia 'Sunny Rose'. MS thesis, Clemson Univ., Clemson, S.C.

Malek, T. and D.A. Baker. 1978. Effect of fusicoccin on proton co-transport of sugars in the phloem loading of Ricinus communis L. (castorbeans). Plant Sci. Lett. 11:233-239.

Mayssek, R., S. Maruyama, and J.S. Boyer. 1988. Rapid wall relaxation in elongating tissues. Plant Physiol. 86:1163-1167.

McCree, K.J. and S.G. Richarson. 1987. Stomatal closure vs. osmotic adjustment: A comparison of stress responses. Crop Sci. 27:539-543.

Moore, K. 1996. Coastal plain, p. 52. In: N. Beaubaire (ed.). Native perennials: North American beauties. Brooklyn Botanical Garden, New York.

Morgan, J.M. 1984. Osmoregulation and water stress in higher plants. Annu. Rev. Plant Physiol. 35:299-319.

Nguyen, H.T., R.C. Babu, and A. Blum. 1997. Breeding for drought resistance in rice: Physiology and molecular genetics considerations. Crop Sci. 37:14261434.

Palta, J.A. and P.J. Gregory. 1997. Drought affects the fluxes of carbon to roots and soil in ${ }^{13} \mathrm{C}$ pulse-labeled plants of wheat. Soil. Biol. Chem. 29:1395-1403.

Pilon-Smits, E.A., M.J.M. Ebskamp, M.J. Paul, M.J.W. Jeuken, P.J. Weisbeek, and C.M. Smeekens. 1995. Improved performance of transgenic fructanaccumulating tobacco under drought stress. Plant Physiol. 107:125-130.

Premancandra, G.S., D.T. Hahn, D. Rhodes, and R.J. Joly. 1995. Leaf water relations and solute accumulation in two grain sorghum lines exhibiting contrasting drought tolerance. J. Expt. Bot. 46:1833-1841.

Ranwala, A.P. and W.B. Miller. 1998. Sucrose-cleaving enzymes and carbohydrate pools in Lilium longiflorum floral organs. Physiol. Plant. 103:541-550.

Raschke, K. 1979. Movements of stomata, p. 383-441. In: W. Haupt and M.E. Feinleib (eds.). Encyclopedia of plant physiology. vol. 7. Physiology of movements. Springer Verlag, Berlin.

Santamaria, J.M., M.M. Ludlow, and S. Fukai. 1991. Contribution of osmotic adjustment to grain yield in Sorghum bicolor (L.) Moench under water-limited conditions. I. Water stress before anthesis. Austral. J. Agr. Res. 41:51-65.

Sharp, R.E. and W.J. Davies. 1989. Regulation of growth and development of plants growing with a restricted supply of water, p. 72-93. In H.G. Jones, T.L. Flowers and M.B. Jones (eds.). Plants under stress. Cambridge Univ. Press, London.

Smith, M., Y. Wu, and O. Green. 1993. Effect of light and water stress on photosynthesis and biomass production of Boltonia decurrens (Asteraceae), a threatened species. Amer. J. Bot. 80:859-864.

Smucker, A.J.M. 1984. Carbon utilization and losses by plant root systems. Amer. Soc. Agron. 49:27-46.

Smucker, A.J.M. 1993. Soil environmental modifications of root dynamics and measurement. Annu. Rev. Phytopathol. 31:191-216.

Tardieu, F. and T. Simonneau. 1998. Variability among species of stomatal control under fluctuating soil water status and evaporative demand: Modeling isohydric and anisohydric behaviours. J. Expt. Bot. 49:419-432.

van den Ende, W. and A. van Laere. 1996. De-novo synthesis of fructans form sucrose in vitro by a combination of two purified enzymes (sucrose:sucrose 1fructosyl transferase and fructan:fructan 1-fructosyl transferase) from chicory roots (Cichorium intybus L.). Planta 200:335-342. 